\title{
Sorteringsprosessen i bevissikringssaker og ved beslag inneholdende taushetsbelagt informasjon
}

\author{
Av Maria Astrup Hjort
}

Hvem skal sortere, og hvordan skal det sorteres? Dette er aktuelle spørsmål både i bevissikringssaker og ved beslag inneholdende taushetsbelagt informasjon etter straffeprosessloven. Forfatteren foretar en komparativ analyse av de to sakstypene vedrørende spørsmålet om håndtering av digitalt lagret materiale.

MARIA ASTRUP HJORT ble cand.jur. i 2006, ph.d. i rettsvitenskap i 2015 og arbeider som postdoktor ved Institutt for offentlig rett, Det juridiske fakultet (UiO).

\section{Innledning}

I de aller fleste saker etter tvisteloven kapittel 28 om bevissikring utenfor rettssak blir sikringen foretatt i form av speilkopiering av digitalt lagret materiale. Dette anses som en hensiktsmessig fremgangsmåte fordi store mengder data kan sikres på kort tid, og fordi materialet kan leveres tilbake straks etter kopieringen, og da uten noen begrensninger i bruken av materialet. Det følger imidlertid flere konsekvenser ved en slik fremgangsmåte. En av dem er alle de rettslige og praktiske spørsmålene knyttet til det omfangsrike materialet namsmannen sitter igjen med når sikringen er gjennomført. I den såkalte Normarc-saken, som på mange måter var en pioner i bruken av denne fremgangsmåten for å få tilgang til bevis, ble det kopiert minst 50000 filer, og dette var antatt å omfatte ca. 285 millioner A4-sider, dersom alt skulle skrives ut på papir. ${ }^{1}$ En slik mengde informasjon kan ikke gjennomgås manuelt, og man må derfor finne en alternativ fremgangsmåte for å finne frem til de relevante bevis. I en speilkopi vil dessuten relevante og irrelevante elementer være sammenfiltret, og det er ikke noen enkel måte å finne frem til det relevante materialet på. Private og sensitive opplysninger, taushetsbelagt informasjon og bedriftshemmeligheter må også sorteres vekk uten at den begjærende part eksponeres for dem.

I straffeprosessen gjøres det bruk av speilkopiering som verktøy for å sikre beslag av digitalt lagret materiale. ${ }^{2}$ Problemet oppstår når det digitale materialet inneholder eller påstås å inneholde taushetsbelagt informasjon, informasjon som politiet ikke kan ta beslag i, jf. straffeprosessloven $\S 204$ første ledd. Ved speilkopiering er det ikke mulig å sortere ut taushetsbelagt informasjon før kopieringen gjøres, og fremgangsmåten er derfor som i bevissikringssakene å kopiere alt og sortere etterpå. Straffeprosessloven gir imidlertid noen klare svar på hvordan denne sorteringsprosessen skal gjennomføres.

Heller ikke tvisteloven gir noen gode svar. Bevissikringskapittelet synes å ta utgangspunkt i mer tradisjonelle realbevis som gjenstander og papirdokumenter, og henvisningen i tvl. $\S 28-4$ om at gjennomføring av bevissikring skal gjøres etter reglene om rådighetsstillelse og bevisopptak «så langt de passer», gir ingen veiledning. Dermed blir sorteringsprosessen svært lite håndfast. Dommeren må selv finne ut av fremgangsmåten $\mathrm{i}$ den enkelte sak og ta stilling til hvilken fremgangsmåte som er mest hensiktsmessig. Uten regler om fremgangsmåten blir det også vanskelig å gi en dekkende beskrivelse av hvordan prosessen «vanligvis» foregår, og forutberegneligheten blir lav.

${ }^{1}$ LB-2005-59502. Saken resulterte i 10 kjennelser registrert i Lovdata, deriblant Rt. 2006 s. 146 og Rt. 2006 s. 626. En beskrivelse av saken gis i Maria Astrup Hjort, Tilgang til bevis $i$ sivile saker - sarlig om digitale bevis, Oslo 2016 s. 266-268.

${ }^{2}$ Se Inger Marie Sunde, «Databevis», i Ragna Aarli, Mary-Ann Hedlund og Sverre Erik Jebens, Bevis i straffesaker. Utvalgte emner, Oslo 2015 s. 599-633. 
Den som begjærer bevissikring er åpenbart ikke egnet til å foreta en sortering av det sikrede materialet, og motparten vil ha et insitament mot å legge frem alt relevant materiale, og er derfor heller ikke egnet til å foreta gjennomgangen. Dommeren på sin side har hverken tid eller ressurser til å foreta sorteringsjobben selv. Situasjonen er den samme for beslag inneholdende taushetsbelagt informasjon. De sentrale spørsmålene er derfor hvem som skal sortere og hvordan det skal sorteres.

Både hvem som skal sortere og hvordan det skal sorteres er spørsmål som dommeren må ta stilling til, og i praksis styrer og leder dommeren en slags granskningsprosess. En slik rolle er i konflikt med vårt bilde av den nøytrale dommeren, all den tid ansvaret for å finne frem bevis i saken er lagt til partene i sivile saker og politiet i straffesaker.

Denne artikkelen belyser rollen som tildeles den som undersøker materiale sikret etter reglene i tvisteloven kapittel 28, og det foretas en komparasjon med beslag av digitalt lagret materiale i straffesaker, der materialet inneholder taushetsbelagt informasjon, jf. straffeprosessloven $\S 204$ første ledd. Som det allerede fremgår, kommer man her opp i mange av de samme problemstillingene som i sivile saker. ${ }^{3}$

\section{Sorteringsprosessen slik den foregår i dag}

Det er retten som styrer sorteringsprosessen i bevissikringssaker etter reglene i tvisteloven, men dommeren i saken har hverken tid eller ressurser til å gjøre jobben selv. Det vanlige er at retten tyr til tvistelovens kapittel 25 om sakkyndigbevis og oppnevner som sakkyndig en person med teknisk kompetanse til å foreta søk i det sikrede materialet. ${ }^{4}$ Den sakkyndige finner frem til det materialet vedkommende anser for å være relevant for saken, og når det aktuelle materialet er skilt ut, vurderes det om det foreligger bevisforbud eller bevisfritak som hindrer tilgang til materialet. I tråd med tvistelovens regler er det vanlig at den sakkyndige utferdiger en skriftlig erklæring i form av en rapport med vedlagte resultater fra søkingsarbeidet. Rapporten forelegges først motparten, slik at vedkommende får mulighet til å markere de bevis som vedkommende mener skal unntas fra tilgang, typisk på grunn av bevisforbuds- eller bevisfritaksregler eller fordi det ikke vedkommer saken, og retten vurderer dennes bemerkninger før utvalget overleveres den begjærende part. Den sakkyndige har senere plikt til å møte for å avgi forklaring i rettsmøte etter innkalling fra retten. ${ }^{5}$

I straffesaker innebærer vanligvis ikke håndtering av beslag av digitalt lagret materiale noe sorteringsproblem. Det er i utgangspunktet politiet som i etterkant av et beslag går igjennom og undersøker det som er beslaglagt, og politiet finner selv fremgangsmåter for å gjøre denne jobben. ${ }^{6}$ Problemet oppstår når det reises spørsmål om beslaget inneholder

${ }^{3}$ Problemer knyttet til håndtering av sikret materiale inneholdende taushetsbelagt informasjon gjør seg også gjeldende på andre områder, blant annet ved forvaltningens kontrollvirksomhet, se Marius Stub, Tilsynsforvaltningens kontrollvirksomhet, Oslo 2011 s. 268 flg. og s. 315 flg., og ved konkurranserettslig bevissikring, se konkurranseloven $\S 25$ fjerde ledd. Disse områdene vil ikke bli behandlet i denne artikkelen.

${ }^{4}$ Dette inntrykket er dels basert på underrettsavgjørelser jeg har mottatt som del av en praksisundersøkelse, se Hjort $2016 \mathrm{~s}$. 59, dels basert på avgjørelser tilgjengelig i Lovdatas databaser. I de avgjørelsene jeg har funnet, blir det ikke henvist til noen hjemmel for oppnevning av den som skal gjøre jobben, men i og med at de blir rettsoppnevnt og blir omtalt som sakkyndige, er det naturlig å anta at man følger reglene om sakkyndigbevis i tvisteloven kapittel 25.

${ }^{5}$ Se tvl. $§ 25-5$ (2).

${ }^{6}$ Straffeprosessloven har også regler om pålegg om sikring av elektronisk lagrede data i $§ 215$ a. 
taushetsbelagt informasjon. Dette er særlig praktisk der beslaget gjøres på et advokatkontor, eller der beslaget påstås å inneholde advokatkorrespondanse. ${ }^{7}$ Dokumenter eller databærere inneholdende taushetsbelagt informasjon er etter strpl. § 204 første ledd unntatt fra beslag og kan ikke gjennomgås av politiet. Dermed har utgangspunktet for håndteringen av beslag inneholdende taushetsbelagt informasjon store likheter med håndteringen av bevissikret materiale i en sivil sak: Noen må sortere det speilkopierte materialet, og partene i saken er ikke egnet. Hvem skal sortere, og hvordan skal det sorteres?

For beslag inneholdende taushetsbelagt informasjon har Høyesterett lagt til grunn en analogi fra strpl. § 205 tredje ledd. ${ }^{8}$ Her skal «dokumentene forsegles i lukket konvolutt» og tas med til retten for avgjørelse. Sorteringsansvaret plasseres altså hos retten, og utgangspunktet er at retten skal «gå igjennom og vurdere det enkelte dokument». ${ }^{9}$ Ved speilkopiering er det imidlertid praktisk talt umulig å gå igjennom alt materialet manuelt. På samme måte som i sivile saker må man derfor basere seg på automatiske søk. Gjennom rettspraksis har det blitt etablert en kutyme for at retten oppnevner en sakkyndig, typisk en advokat, som har det overordnede ansvaret for gjennomgangen av det sikrede materialet. I tillegg oppnevnes det en teknisk assistent som foretar søkene. ${ }^{10}$ I straffesaker er det dermed i motsetning til i sivile saker - to personer med hver sin kompetanse som samarbeider om sorteringsarbeidet.

Beslag som inneholder taushetsbelagt materiale, kan deles i to typetilfeller. ${ }^{11}$ I det ene tilfellet er det fremsatt en pretensjon om at beslaget inneholder opplysninger som er undergitt taushetsplikt, jf. strpl. § 204 første ledd, og her vil sorteringen være rettet mot det materialet politiet $i k k e$ får se, og resten tilgjengeliggjøres. Det skal med andre ord ikke foretas noen relevansvurdering, bare en vurdering av hva som er taushetsbelagt.

Det andre tilfellet gjelder materiale som med sikkerhet inneholder opplysninger underlagt taushetsplikt, men hvor politiet anfører unntak for beslagsforbudet, jf. strpl. § 204 annet ledd, typisk der beslaget er gjort hos en advokat. Her skal det $-\mathrm{i}$ likhet med $\mathrm{i}$ bevissikringssakene - foretas både en relevansvurdering av materialet $o g$ en vurdering av om innholdet er taushetsbelagt. Søkene vil være rettet mot det politiet skal få lov til å se, og resten tilgjengeliggjøres ikke. Det er med andre ord en betydelig forskjell på hvor mye data en sitter igjen med etter sorteringen ved de to typetilfellene, og innfallsvinkelen har også betydning for hvordan sorteringsarbeidet bør angripes.

Hvordan materialet sorteres rent faktisk, har man løst fra sak til sak, og det gjelder for både bevissikringssakene og beslagssakene. Materialet vil som regel være så omfattende at det ikke er aktuelt å sortere i ordets rette forstand. I bevissikringssakene er det vanlig at partene blir enige om relevante søkeord, og at retten pålegger den sakkyndige å foreta søk i

\footnotetext{
${ }^{7}$ Søk i Lovdata 18.11.16 i HRSTR, LASTR, LBSTR, LESTR, LGSTR, LFSTR, LHSTR, LXSTR og TRSTR, dvs. straffesaker i alle instanser, med søkeordet «LOV-1981-05-2225-§204», dvs. alle avgjørelser der strpl. § 204 er nevnt, samt emneordet «speilkopi», ga 13 treff. Av disse gjaldt 12 avgjørelser informasjon hos advokat eller til advokat underlagt taushetsplikt. Se for $\varnothing$ vrig Jon Petter Rui, «Om advokaters taushetsplikt og ransaking og beslag ved advokatkontor», Tidsskrift for strafferett, 03/2013 s. 297-341.

${ }^{8}$ Rt. 1986 s. 1149, med videre henvisning på s. 1154-1155 til Ot.prp. nr. 53 (1983-1984) s. 63.

${ }^{9}$ Hans-Petter Jahre, «Ransaking og beslag hos advokater og revisorer i økonomiske straffesaker. Særlig om forholdet til taushetsplikt», i Nils Christie, Asbjørn Kjønstad, Peter Lødrup, Svein Slettan og Carsten Smith (red.), ...den urett som ikke rammer deg selv. Festskrift til Anders Bratholm 70 år, Oslo 1990 s. 251-266, på s. 260 og 264.

${ }^{10}$ Rt. 2013 s. 968 (46).

${ }^{11}$ Oslo tingretts retningslinjer for behandling av beslag nr. 2014/14.
} 
det sikrede materialet med disse. Blir partene ikke enige, må retten ta en avgjørelse om hvilke søkeord som skal benyttes. I beslagssakene vil valg av søkeord avhenge av hvilket typetilfelle man står ovenfor. For typetilfelle 1, der man bare skal sile vekk taushetsbelagt informasjon, typisk i form av advokatkorrespondanse, vil søkeordene kunne være generelle termer som «advokat», «forsvarer» eller «advokatfirma». Ved typetilfelle 2 må man derimot, som i bevissikringssakene, finne frem til termer som gir best mulig treff på den informasjonen man $\emptyset n s k e r$ å finne frem til. Dersom en advokat siktes sammen med en eller flere klienter, vil relevante søkeord for eksempel være de aktuelle klienters navn, telefonnummer og epostadresse. Her vil påtalemyndigheten, forsvarer og dommer måtte samarbeide om søkeord og prosedyrer. Teknikeren utfører søkene, og den sakkyndige foretar en vurdering av treffene.

Søkeordene velges etter nøye overveielse. Ordet må være såpass spesifikt at søket gir færrest mulig irrelevante treff, samtidig som det ikke må være så langt eller spesielt at sentrale bevis ikke fanges opp. Selv om søkeordet er fornuftig og relevant, kan søk i et større sikret materiale gi så mange treff at heller ikke denne informasjonsmengden lar seg undersøke manuelt. Om det da skal gjøres et utvalg av treffene, og hvordan dette i så fall skal gjøres, finnes det lite tilgjengelig praksis om. Å foreta et utvalg av treff kan dessuten vanskelig gjøres representativt uten å kjenne innholdet $\mathrm{i}$ alle treffene. Man risikerer at eksemplene som den sakkyndige plukker frem, bare er toppen av et isfjell, der det er uvisst hva som befinner seg under overflaten. For å foreta et slikt utvalg må det i det minste klart fremgå hvilke kriterier utvalget er basert på. ${ }^{12}$ Foretar den sakkyndige et utvalg, vil den begjærende part bare få tilgang til disse utvalgte filene. Uansett vil den begjærende part aldri kunne få oversikt over og kunnskap om den totale mengden sikret materiale, og muligheten for at et avgjørende bevis ikke er lokalisert, vil alltid være tilstede.

Dersom treffene ikke gjennomgås manuelt, kan det vanskelig sies noe eksakt om mengden relevante treff, og heller ikke om bevisverdien i det enkelte treff. De utvalgte bevisene det gis tilgang til blir bare eksempler på at denne typen datamateriale finnes der det er foretatt bevissikring. Feilkildene til treff kan være mange, og det kan finnes andre gode forklaringer på at et bestemt søkeord gir treff på bestemte filer eller på bestemte lagringsmedier enn den som legges til grunn for kravet. Et beskrivende eksempel fra straffeprosessen er søk i digitalt lagret materiale, beslaglagt grunnet mistanke om besittelse av barnepornografi. Et søk på ordet «anal» vil i mange tilfeller være helt intetsigende fordi det også vil gi treff på en mengde andre ord som er irrelevante i sammenhengen, eksempelvis «analyse», «kanal» og «analogi». Dersom det ikke tas høyde for slike feilkilder, vil resultatet av et $s ø \mathrm{k}$ ha liten verdi.

\section{Den sorterendes mandat}

Den som sorterer må ha et mandat å jobbe ut fra. Både i bevissikringssakene og i de beskrevne beslagssakene er ansvaret for å utferdige mandatet lagt til retten, men ingen av disse to sakstypene har noen lovbestemte retningslinjer for hvordan mandatet skal utformes. ${ }^{13}$ Det skyldes antagelig at det ved bruk av sakkyndige i mer tradisjonell forstand heller ikke er nødvendig med noen retningslinjer. Retten vil for eksempel uten behov for ytterligere retningslinjer kunne be en mikrobiolog vurdere hva slags sopp som finnes i veggen, eller en rettsmedisiner vurdere om DNA-beviset passer med tiltaltes DNA. Ved sortering av digitalt lagret materiale er det ikke den sakkyndiges syn på innholdet som er konklusjonen, men

${ }^{12}$ Se LB-2009-110691, der den sakkyndiges rapport inneholdt enkelte «eksempler» på eposter som gav treff på søk i e-postkassene.

${ }^{13}$ Både tvl. § 25-4 og strpl. § 142 a legger opp til at retten skal fastsette mandatet og gi de nødvendige instrukser, men at retten kan pålegge partene å utarbeide forslag til mandat for den sakkyndige. 
hvilken kategori informasjonen havner i. Den som sorterer må forholde seg til materiale som ikke vedrører saken og som i noen tilfeller også er av sensitiv karakter, eller er taushetsbelagt. Mandatet gir derfor en viktig ramme rundt arbeidet. Jo videre og mer generell utformingen av mandatet er, jo vanskeligere er det for den sakkyndige å gjøre en god jobb. Særlig i de tilfellene den sakkyndige må gjøre en relevansvurdering av materialet, er man avhengig av et presist mandat for å få svar på det man lurer på. For den som er satt til å sortere, kan det være lett å gå fra å sortere til å mene noe om innholdet.

Det er stor variasjon i utformingen av slike mandat. I noen mandater gis den sakkyndige i oppgave å svare på spørsmål på bakgrunn av det vedkommende har funnet i det sikrede materialet, uten at det angis noen fremgangsmåte for gjennomgangen av materialet. ${ }^{14} \mathrm{I}$ andre mandater utformes det noen særskilte søkeord, og den sakkyndige får ellers frie fullmakter til å gjøre seg opp et standpunkt på bakgrunn av det sikrede materialet. ${ }^{15}$ Et eksempel er utformingen av den sakkyndiges mandat i Normarc-saken:

«[...] Den sakkyndige anmodes om å foreta en gjennomgang og analyse av det sikrede bevismaterialet for å avklare om, og eventuelt i hvilket omfang, det inneholder dokumenter eller opplysninger av bedriftsintern karakter og som antas å kunne tilhøre eller ha sin opprinnelse hos Normarc. Den sakkyndige fastlegger selv på hvilken måte det skal gås frem for å gjennomføre oppdraget [...]». ${ }^{16}$

Med et så vidt mandat er det vanskelig for den som sorterer å unngå å mene noe om realiteten i saken. I beslagssakene synes mandatet å være klarere utformet, og det skyldes antagelig den etablerte todelingen av typetilfeller som beskrevet ovenfor, der det er bevissthet om hvorvidt sorteringen kun skal gjøres etter vurdering av om materialet er taushetsbelagt, eller om den som sorterer også skal vurdere relevansen av materialet. Også det at man legger opp til et samarbeid mellom en tekniker som søker og en oppnevnt som foretar selve sorteringen er med på å danne rammer for denne prosessen og for mandatene, selv om den ikke er lovregulert.

Den doble kompetansen som kreves for å gjennomgå en speilkopi, gjør det hensiktsmessig også i sivile saker å dele sorteringsarbeidet mellom to personer, én tekniker og én person med forståelse for innholdet i materialet. Et eksempel på en slik oppdeling finnes i en bevissikringskjennelse fra Haugaland tingrett av 6. juni 2014. ${ }^{17}$ Her ble gjennomgangen av det sikrede materialet etter forslag fra den begjærende part delt i to trinn, ikke ulikt sorteringen i beslagssakene. I trinn 1 skulle det gjennomføres en teknisk gjennomgang av det sikrede materialet i form av en rekke automatiserte $s \varnothing \mathrm{k}$ med utvalgte søkeord, begrenset til treff innenfor visse tidsangivelser og til data fra to angitte selskaper, for å innsnevre dokumenttilfanget mest mulig. Deretter skulle det gjennomføres en «manuell hel eller delvis gjennomgang av søkeresultatene (trinn 2), utført av en annen sakkyndig etter særskilt mandat». ${ }^{18}$ Det fremgår ikke av kjennelsen hvilken bakgrunn den sakkyndige som skal utføre trinn 2 skal ha, annet enn at vedkommende skulle «oppnevnes av retten etter forslag fra partene og etter mandat fastsatt av retten til å gjennomgå materialet og at en deretter tar stilling til hvilket materiale som skal gjøres tilgjengelig for rekvirenten». ${ }^{19}$ En kan tenke seg flere typer fagpersoner som kan være hensiktsmessig å oppnevne for trinn 2 av gjennomgangen. Avhengig av saksforholdet kan det være aktuelt å oppnevne en sakkyndig med særlig kompetanse innenfor det fagområdet saken dreier seg om. Alternativt kunne man

\footnotetext{
${ }^{14}$ LB-2012-177534, LB-2013-52503.

${ }^{15}$ LB-2010-149042.

${ }^{16}$ LB-2010-149042 s. 7 i domstolens originalversjon av kjennelsen.

17 13-078806TVI-HAUG.

18 13-078806TVI-HAUG s. 4 og s. 6 i domstolens originalversjon av kjennelsen.

${ }^{19}$ 13-078806TVI-HAUG s. 16 i domstolens originalversjon av kjennelsen.
} 
oppnevnt en jurist med praktisk erfaring fra det fagfeltet saken dreier seg om. Det kan også tenkes sakkyndige med annen kompetanse. Det sentrale er at vedkommende må ha en forståelse for hvilken informasjon som har bevisverdi og hvilken som raskt kan sorteres vekk.

Selv om det tekniske arbeidet og arbeidet med å finne frem til bevis er delt $\mathrm{i}$ to trinn, løser ikke dette alle vanskeligheter ved gjennomgangen av materialet. En innsnevring av materialet basert på forhåndsbestemte søkeord vil redusere mengden irrelevant materiale, men man unngår ikke problemet med bevis underlagt bevisforbud og bevisfritak. Det vil lett kunne tenkes filer som gir treff på søkeordene, men som likevel kan unntas. Den sakkyndige nr. 2 vil dermed også kunne komme i den situasjon at vedkommende kjenner til informasjon som ikke skal brukes som bevis i saken. I noen tilfeller vil de sentrale bevisene også inneholde driftseller forretningshemmeligheter. Dersom det for eksempel er mistanke om at selve kildekoden til et dataprogram er kopiert og benyttet $i$ en annen sammenheng enn det eieren av kildekoden har gitt tillatelse til, vil kildekoden i seg selv være en drifts- eller forretningshemmelighet. Det kan imidlertid ikke være til hinder for å oppnevne en sakkyndig til å sammenligne

kildekodene. Den sakkyndige må i slike tilfeller bare kunne uttale seg om generelle spørsmål i etterkant, og ikke gå i detalj om innholdet i kildekoden. Balansegangen mellom å skulle begrunne sine standpunkt og samtidig ikke røpe drifts- eller forretningshemmeligheter vil her være et problem.

Uten lovregulering eller andre former for rettslig regulering vil det antagelig ta lang tid før det gjennom praksis er utarbeidet retningslinjer for hvordan dommerens mandat til den sakkyndige bør utformes og hvordan både retten og den sakkyndige skal kunne gjennomføre sorteringsfasen på en mest mulig hensiktsmessig måte. Eksempelet fra Haugaland tingrett er imidlertid et skritt i riktig retning.

\section{Håndtering av taushetsplikt under sorteringsarbeidet}

Spørsmålet om håndtering av beslag inneholdende taushetsbelagt informasjon kom opp i Rt. 2013 s. 968. For beslagssaker kunne Høyesterett «ikke se at noe er til hinder for at en uavhengig datakyndig engasjeres av retten til å foreta de nødvendige $s \varnothing \mathrm{k} » .{ }^{20}$ Den sentrale grunnen til å oppnevne noen til å håndtere sorteringsarbeidet ved beslag inneholdende taushetsbelagt materiale var ikke at taushetsplikten og taushetsretten ble krenket. ${ }^{21}$ Høyesterett henviste her til lagmannsrettens uttalelse om at «kravet i straffeprosessloven $\S 205$ tredje ledd in fine, [viser] at formålet er å skille skarpt mellom politiets og rettens befatning med materiale fra en ransaking». ${ }^{22}$ Det er likevel ikke til å komme unna at sorteringsprosessen i realiteten er et ledd i en pågående ransaking. ${ }^{23}$ For å kunne sortere vekk det taushetsbelagte materialet må noen lese såpass mye av informasjonen at vedkommende kan ta stilling til om informasjonen er underlagt taushetsplikt eller ikke. Noen må sortere materialet, og når dommeren selv ikke har tid og ressurser til å håndtere dette selv, er det mer en prinsippsak om man velger å legge dette arbeidet til en rettsoppnevnt person eller til politiet. Når det først åpnes for å benytte speilkopiering, er det en nødvendig konsekvens at den taushetsbelagte informasjonen må gjøres tilgjengelig for noen som ikke knyttes til informasjonen gjennom taushetsplikt eller -rett.

Spørsmål knyttet til sortering av taushetsbelagt informasjon finner man også i bevissikringssakene, typisk fordi det sikrede materialet inneholder drifts- eller forretningshemmeligheter. I straffesaker er det å skille taushetsbelagt informasjon fra resten av materialet en sentral del av den sakkyndiges sorteringsarbeid før materialet kan overleveres

\footnotetext{
${ }^{20}$ Rt. 2013 s. 968 (46).

${ }^{21}$ NUT 1969: 3 s. $252-253$.

${ }^{22}$ Rt. 2013 s. 968 (41).

${ }^{23}$ Se Knut Svalheim, Advokaters taushetsplikt, Oslo 1996 s. 222.
} 
til politiet. I sivile saker kommer problemstillingen opp mer som et sidespørsmål på letingen etter bevis. Det er selvfølgelig et mål å begrense tilgangen til taushetsbelagt informasjon, men den sakkyndige må få full tilgang til materialet, herunder informasjon underlagt bevisforbud og bevisfritak for å kunne gjennomføre sorteringsarbeidet.

I tillegg til den sakkyndiges skriftlige rapport, utformet under saksforberedelsen, er det vanlig at retten innkaller den sakkyndige til å avgi forklaring under hovedforhandling i saken. En gjennomgang av et sikret materiale kan ta lang tid, og det vil etter hvert være umulig for den sakkyndige å huske hvilken informasjon som er underlagt taushetsplikt. Men er den sakkyndige bevisst denne problemstillingen? I noen kjennelser blir det presisert hvilket faktisk materiale den sakkyndige skal uttale seg om, men i andre tilfeller er en slik distinksjon helt fraværende. Når den sakkyndige ikke blir orientert om dette forholdet, har vedkommende ingen insentiver til å se bort fra deler av informasjonen. Uten forutsetninger for det kan det dessuten være vanskelig for den sakkyndige å avgjøre om informasjonen er underlagt taushetsplikt eller ikke. Dersom den sakkyndige blir ute av stand til å svare på spørsmål, blir det vanskelig å gjøre jobben som sakkyndig. Konklusjonen er vel at det å gi en sakkyndig full tilgang og deretter be vedkommende svare på spørsmål ikke er noen tilfredsstillende løsning på hvordan sorteringsprosessen bør håndteres.

Etter domstolloven $\S 63$ a skal dommere «og andre som utfører tjeneste eller arbeid for et dommerkontor» hindre at «andre» får adgang eller kjennskap til det de i forbindelse med tjenesten eller arbeidet får vite om noens personlige forhold, tekniske innretninger eller fremgangsmåter, drifts- eller forretningsforhold som det vil være av konkurransemessig betydning å hemmeligholde av hensyn til den som opplysningen angår. Det er slått fast av Høyesteretts ankeutvalg at den rettsoppnevnte sakkyndige i en straffesak var omfattet av denne bestemmelsen. ${ }^{24}$ Jeg legger til grunn at også rettsoppnevnte i sivile saker må anses omfattet. Det blir beskrevet i både praksis og litteratur hvilken informasjon som skal være omfattet av taushetsplikten, men det blir ikke problematisert hvem «andre» er. Antagelig er pålegget ment som et forbud mot å snakke med utenforstående om taushetsbelagt informasjon. Mer interessant er det imidlertid om den sakkyndige til et visst punkt også bør ha taushetsplikt overfor aktørene i saken og begrense formidling av innholdet i materialet til sakkyndigrapporten. Dersom den sakkyndige snakker med den begjærende part om innholdet, vil vedkommende kunne komme til å røpe informasjon som er underlagt bevisforbud eller bevisfritak. Snakker den sakkyndige med dommeren om innholdet, vil dommeren kunne forhindres fra å dømme i den saken beviset skal brukes i, fordi han kan få vite om informasjon som kan være av betydning for saken, men som på grunn av taushetsplikten ikke skal inngå i avgjørelsesgrunnlaget. I teorien kan den sakkyndige snakke med motparten om innholdet i det sikrede materialet, for vedkommende sitter med samme materialet selv, men for å forhindre at den sakkyndige styres av motpartens antatte ønske om å unnta tilgang til informasjon som ikke vil gagne ham, bør heller ikke disse snakke sammen om innholdet i det sikrede materialet. Konklusjonen er dermed at den sakkyndige strengt tatt ikke bør konferere med noen av sakens aktører, noe som forutsetter et klart mandat.

I forlengelsen av spørsmålet om taushetsplikt kan man også tenke seg at den sakkyndige kommer over kompromitterende informasjon som ikke nødvendigvis vedrører saken, men som kan være viktige bevis for eksempel i en straffesak. Eksempler kan være korrespondanse som avslører hvitvasking eller bilder med barnepornografisk innhold. Har den sakkyndige taushetsplikt også hva gjelder denne informasjonen? Eksemplene viser at den sakkyndiges rolle i bevissikringssaker er lite klargjort, og at den sakkyndige kan komme opp i uforutsette problemstillinger. Et klart mandat vil kunne være med på å løse slike spørsmål.

\footnotetext{
${ }^{24}$ HR-2011-1948-U (16).
} 


\section{5 «Sakkyndig» - rette rollen?}

Et sakkyndigbevis defineres i tvl. § 25-1 som en «fagkyndig vurdering av faktiske forhold i saken». Straffeprosessloven kapittel 11 gir ingen definisjon av hverken sakkyndige eller sakkyndigbevis, men i utkast til ny straffeprosesslov (NOU 2016: 24) § 11-1 omtales sakkyndige som «personer med særlig kunnskap eller erfaring på et bestemt felt». Typiske eksempler er leger som uttaler seg om kroppslige skader, ingeniører som uttaler seg om byggkonstruksjoner og psykologer som uttaler seg om en persons psykiske helse.

I bevissikringssaker og ved beslag inneholdende taushetsbelagt informasjon brukes sakkyndigrollen på en annen måte enn det som er vanlig. Istedenfor at den sakkyndige blir oppnevnt på grunn av sin kompetanse til å foreta sakkyndig vurdering av bevisene, blir vedkommende oppnevnt på bakgrunn av sin kunnskap om å foreta $s \phi k$ etter bevis. I bevissikringssakene vil den sakkyndige oppnevnes på bakgrunn av sin tekniske kompetanse. Vurderinger av de bevis som befinner seg i det sikrede materialet, vil den sakkyndige vanligvis ikke ha bedre forutsetning enn andre for å foreta. Uttalelser fra litteraturen om at sakkyndigerklæringer er et «autoritativt bevis», får med andre ord ikke betydning i denne sammenheng. ${ }^{25}$ Tvert imot, man kan risikere at den sakkyndige ikke forstår betydningen av den informasjonen vedkommende finner i sitt arbeid med speilkopien, og ikke får frem de aktuelle bevis i saken. $\AA$ overlate hele undersøkelsen til denne sakkyndige kan sammenlignes med å spørre arkivaren om betydningen av innholdet i mappene i arkivet. Arkivaren kan finne frem de mappene man spør etter, men har ingen særlig kompetanse til å si noe om innholdet i det som er arkivert.

I beslagssakene stiller det seg til en viss grad annerledes. Det er vanlig at arbeidet med sorteringen blir gitt to personer med ulik kompetanse, og den teknisk sakkyndige er skjøvet ut av sakkyndigrollen og opptrer som datatekniker. Det er bare den som vurderer treffene - som oftest en advokat - som er oppnevnt som sakkyndig, og det kan argumenteres for at vedkommende er sakkyndig hva gjelder vurderingen av hva som er taushetsbelagt. En delegering av juridisk arbeid er imidlertid i konflikt med den tradisjonelle oppfatningen av sakkyndige. Straffeprosessutvalget uttaler om sakkyndig bistand at «[h]vis sakens aktører ikke har kunnskap til å bedømme bevisene forsvarlig på egen hånd, kan de få bistand utenfra». ${ }^{26}$ I dette tilfellet er det imidlertid ikke snakk om at sakens aktører mangler evne til å vurdere bevisene. Problemet er at hverken påtalemyndigheten eller for den saks skyld forsvarerne anses egnet til å gjøre jobben, og dommeren har ikke tid. Sakkyndigoppdraget er simpelthen en delegering av arbeid fra dommerens bord. Den oppnevnte gjør likevel bare en vurdering av om beviset kommer i den ene eller andre kategorien, ikke en vurdering av innholdet $\mathrm{i}$ beviset, slik det for eksempel er når rettsmedisinere konkluderer med om tiltalte har et DNA som passer med DNA-spor på åstedet. Den sakkyndige i beslagssakene trekker altså ingen slutninger på bakgrunn av innholdet $\mathrm{i}$ beviset.

At sakkyndigrollen ikke er treffende for det arbeidet som gjøres, viser seg enda klarere om man ser på hvordan straffeprosessloven og tvisteloven legger opp til at arbeidet fra den sakkyndige skal håndteres. I begge lover er det regulert at den sakkyndige skal gi en skriftlig

${ }^{25}$ Henrik Zahle, Om det juridiske bevis, København 1976 s. 533 flg. og Anders Løvlie, «Sakkyndigbeviset», i Ragna Aarli, Mary-Ann Hedlund og Sverre Erik Jebens, Bevis $i$ straffesaker. Utvalgte emner, Oslo 2015 s. 537-561. I utredningen «Kunnskapsløft og kommunikasjonsbehov», avgitt 6. oktober 2014 fra et utvalg nedsatt av Advokatforeningen, Dommerforeningen, Riksadvokaten og Regjeringsadvokaten for utarbeidelse av retningslinjer for sakkyndigarbeid i domstolene, er denne formen for sakkyndigarbeid ikke behandlet, se for eksempel om bruk av rettsoppnevnt sakkyndig i utredningens s. 22-27.

${ }^{26}$ NOU 2016: 24 s. 587. 
erklæring ${ }^{27}$ og vitne ${ }^{28}$ i saken dersom retten innkaller den sakkyndige. Den skriftlige erklæringen i disse sakene er imidlertid ikke en «fagkyndig vurdering av faktiske forhold som utgjør bevis i saken». ${ }^{29}$ Under vitneforklaringen kan de sakkyndige selvfølgelig forklare hvilke søkeord de har benyttet og hvilke fremgangsmåter som er benyttet for å håndtere materialet, men konklusjonen fra den sakkyndige i disse sakene er bare hvilke bevis som den begjærende part eller påtalemyndigheten får se, alternativt hva de ikke får se.

Det er utarbeidet retningslinjer for sakkyndigarbeid i domstolene, og ved avgjørelsen av om retten bør oppnevne sakkyndige, blir det trukket frem flere hensyn som skal tas i betraktning. ${ }^{30}$ Et av dem er «[o]m det bevistema den sakkyndige er begjært oppnevnt for å belyse kan opplyses tilstrekkelig godt gjennom andre bevismidler». ${ }^{31}$ De sakkyndige i de sakene denne artikkelen handler om, belyser ikke noe bevistema. De finner bare frem til bevismidler. Hvilke slutninger man kan dra fra innholdet $\mathrm{i}$ bevisene fra det sikrede eller beslaglagte materialet, er det dommerens jobb å vurdere.

Det er flere eksempler på at den som er oppnevnt som sakkyndig i bevissikringssaker uttaler seg om innholdet i materialet. At vedkommende går utenfor sin rolle er likevel ikke noe argument for at vedkommende er sakkyndig i ordets rette forstand. I Normarc-saken, som ble beskrevet innledningsvis, ble det overfor Borgarting lagmannsrett påpekt av Normarcs prosessfullmektig at «[r] ealiteten synes å være at tingretten langt på vei har delegert sin judisielle funksjon mht innsynsspørsmålet til den oppnevnte IT-sakkyndige». ${ }^{32}$ Også i saken Meawallet AS og Lars Sandtorv mot Petroservice AS, som gjaldt erstatning for urettmessig bruk av programvare, ble dette problemet påpekt. ${ }^{33}$ Den sakkyndige var satt til å sortere materialet og konkluderte i sin rapport med at «funnene inkluderer klare tegn på at kildekode er kopiert fra TrustNordics AS og mest sannsynlig benyttet». Den sakkyndige tok dermed stilling til sakens realitet, og beveget seg med det langt utenfor sin rolle og sitt mandat.

Konklusjonen må være at sakkyndigrollen er myntet på noe annet enn det den blir benyttet til i bevissikringssaker og ved beslag inneholdende taushetsbelagt informasjon. Den som skal sortere bevis, skal vurdere beviset kun med sikte på å plassere det i en kategori og ikke for å trekke slutninger på bakgrunn av bevisene. Og dersom man setter samme person til begge deler, må det være fordi vedkommende også har en særlig kompetanse til å vurdere innholdet i beviset. Både tvisteloven og straffeprosessloven trenger bestemmelser om sorteringsprosessen i disse sakene, og det burde utformes regler om hvem som skal sortere, rammer for den sorterendes rolle og hvordan det skal sorteres.

\section{Veien videre}

I utkast til ny straffeprosesslov er det i § 19-9 åpnet for å i forskrifts form få regulert fremgangsmåten ved behandlingen av databeslag, herunder om hvem som kan bistå retten ved behandlingen. ${ }^{34}$ Slike forskrifter foreligger foreløpig ikke. Etter min mening er det synd at straffeprosessutvalget velger å ikke utforme noen regler om sorteringsprosessen. ${ }^{35}$ Det er synd

${ }^{27}$ Tvl. § 25-5 (1) og strpl. § 143.

${ }^{28}$ Tvl. § 25-5 (2)-(4) og strpl. § 144.

${ }^{29}$ Tvl. § 25-1.

${ }^{30}$ Dommerforeningen, Riksadvokaten, Regjeringsadvokaten og Advokatforeningen, Retningslinjer for sakkyndigarbeid $i$ domstolene. Om utarbeidelse og bruk av sakkyndig bidrag i sivile saker og straffesaker, november 2014.

${ }^{31}$ Retningslinjene s. 4.

${ }^{32}$ LB-2009-110691.

${ }^{33}$ LB-2016-155886.

${ }^{34}$ NOU 2016: 24 Ny straffeprosesslov s. 55.

${ }^{35}$ Se vurderinger i NOU 2016: 24 s. 336-341. 
at straffeprosessutvalget ikke tar stilling til disse spørsmålene. I utvalgets mandat blir det fremhevet som en forutsetning for en god straffeprosess at «den må åpne for rasjonell bruk av moderne informasjonsteknologi». ${ }^{36}$ Rett nok er utredningens kapittel 6 viet «Informasjons- og kommunikasjonsteknologi», men kapittelet retter seg mot aktørenes bruk av IKT, og nevner ikke temaer der teknologien gir opphav til rettslige og praktiske spørsmål under saksgangen, som for eksempel håndtering av digitalt lagrede bevis. Når lovens bestemmelser ikke er tilpasset moderne informasjonsteknologi, er ikke løsningen å lage en hjemmel for forskrifter. I vårt teknologiske samfunn er bruken av digitale verktøy for å utarbeide skriftlig materiale hovedregelen og ikke unntaket. Det må da kunne forventes at $\mathrm{i}$ alle fall omrisset av håndteringen $\mathrm{av}$ beslag $\mathrm{av}$ digitalt lagret materiale reflekteres $\mathrm{i}$ en ny straffeprosesslov.

Både ved bevissikring og ved beslag inneholdende taushetsbelagt informasjon er det dessuten på tide å se på muligheten for å etablere en ny rolle for dem som skal bistå retten med å sortere digitalt lagret materiale. Arbeidet bør deles i to, med en tekniker som foretar søkene og en med egnet kompetanse som vurderer treffene. Sistnevntes rolle kan minne om en form for rettslig medhjelper, slik tvisteloven åpner for i § 3-7. Bestemmelsen knytter imidlertid rettslige medhjelpere til en part i saken og ikke til dommeren, og er derfor ikke egnet slik den er formulert i dag. Den sorterende fungerer som rettens medhjelper og utfører nettopp det arbeidet dommeren selv ikke har tid og ressurser til å foreta, men som ligger innenfor dommerens kompetanse. En mulighet er å gi sistnevnte en utrederrolle. Det bør ved etableringen av en slik rolle utarbeides et eget regelverk om bruk av en slik utreder eller medhjelper, herunder regler om mandat og hvordan vedkommende skal gå frem i sorteringsprosessen.

I min artikkel «Behov for reformering av tvistelovens bevissikringsregler», inntatt først i dette temaheftet, trekker jeg frem mange argumenter for at bevissikringsreglene er modne for revisjon. Behovet for regulering av sorteringsprosessen er ytterligere beskrevet i denne artikkelen, og er nok et argument for samme konklusjon. Fredrik Bøckman Finstads invitasjon til dialog om endringsbehov i tvisteloven er derfor herved besvart. ${ }^{37}$

\footnotetext{
${ }^{36}$ NOU 2016: 24 s. 95.

${ }^{37}$ Fredrik Bøckman Finstad, «Tvisteloven - evaluering og endringsbehov», Lov og Rett, 2016 s. 224-229, på s. 224. Se for øvrig også Ole-Martin Gangnes, «Debatt om evaluering av tvisteloven. Tvisteloven en delvis suksess - men kostnadene har ikke gått ned», Juristkontakt, nr. 8/2016 s. 26-28.
} 